\title{
A New Oxidovanadium(IV) Complex of Oxodiacetic Acid and dppz: Spectroscopic and DFT Study. Antitumor Action on MG-63 Human Osteosarcoma Cell Line
}

\author{
Ignacio E. León • Beatriz S. Parajón-Costa • \\ Carlos A. Franca • Susana B. Etcheverry • \\ Enrique J. Baran
}

Received: 10 November 2014 / Accepted: 10 December 2014 / Published online: 23 December 2014

(C) Springer Science+Business Media New York 2014

\begin{abstract}
The oxidovanadium(IV) complex of oxodiacetic acid $\left(\mathrm{H}_{2} \mathrm{ODA}\right)$ and dppz (dipyrido[3,2-a:2', $3^{\prime}$-c] phenazine) of stoichiometry [VO(ODA)(dppz)] $3 \mathrm{H}_{2} \mathrm{O}$ could be synthesized for the first time by reaction between $\left[\mathrm{VO}(\mathrm{ODA})\left(\mathrm{H}_{2} \mathrm{O}\right)_{2}\right]$ and dppz. It was characterized by infrared and electronic spectroscopies. Its optimized molecular structure was obtained by DFT calculations, as it was impossible to grow single crystals adequate for crystallographic studies. The antitumor action of the complex on MG-63 human osteosarcoma cell line was also investigated. It was found that it caused a concentration-related inhibitory effect in the concentration range between 5 and $25 \mu \mathrm{M}$ and diminished the cell viability ca. $45 \%$ in the range from 25 to $100 \mu \mathrm{M}$, without dose/response effects in this range. These biological effects are, in general, similar to those previously reported for the related $[\mathrm{VO}(\mathrm{ODA})($ ophen $)] \cdot 1.5 \mathrm{H}_{2} \mathrm{O}$ complex.
\end{abstract}

Keywords Oxidovanadium(IV) - Oxodiacetic acid · dppz · DFT calculations · FTIR spectrum · Electronic spectrum . Human osteosarcoma cell line

\section{Introduction}

As part of a research project devoted to the characterization of vanadium compounds with potential pharmacological

I. E. León · S. B. Etcheverry

Cátedra de Bioquímica Patológica, Facultad de Ciencias Exactas,

Universidad Nacional de La Plata, 1900 La Plata, Argentina

I. E. León • B. S. Parajón-Costa • C. A. Franca $\cdot$ S. B. Etcheverry $\cdot$

E. J. Baran $(\square)$

Centro de Química Inorgánica (CEQUINOR/CONICET, UNLP),

Facultad de Ciencias Exactas, Universidad Nacional de La Plata,

C. Correo 962, 1900 La Plata, Argentina

e-mail: baran@quimica.unlp.edu.ar applications, we have recently prepared and investigated the general physicochemical properties and the biological activity of some ternary oxidovanadium(IV) complexes containing the di-anion of oxodiacetic acid $\left(\mathrm{H}_{2} \mathrm{ODA}\right)$ and $\mathrm{H}_{2} \mathrm{O}$, $\left[\mathrm{VO}(\mathrm{ODA})\left(\mathrm{H}_{2} \mathrm{O}\right)_{2}\right][1,2]$ or the organic ligands $o$ phenanthroline (ophen), [VO(ODA)(ophen)] $1.5 \mathrm{H}_{2} \mathrm{O}[1,3]$ and 2,2'-bipyridine (bipy), [VO(ODA)(bipy)] $\mathrm{H}_{2} \mathrm{O}[1,4]$.

Oxodiacetate is a very interesting and versatile ligand, having five potential O-donor atoms in different orientations, allowing in this way the construction of networks of different dimensionalities [5]. In the case of the three above mentioned complexes, which present a distorted octahedral geometry, ODA occupies three coordination positions through two carboxylate $\mathrm{O}$-atoms and the ethereal $\mathrm{O}$-atom, generating the unprecedented tridentate $\mathrm{OOO}$ coordination [6-8].

Metallointercalators are small complex molecules that contain a planar aromatic heterocycle functionality which can insert and stack between the base pairs of double-helical DNA $[9,10]$. In general, upon binding to DNA, metal complexes are stabilized through a series of weak interactions such as the $\pi$-stacking interactions of aromatic heterocyclic groups between the base pairs (intercalation), hydrogen bonding and van der Waals interactions of functional groups bound along the groove of the DNA helix [9].

Two of the best known and most investigated DNA intercalators are 2,2'-bipyridine and $o$-phenanthroline [9, 10]; but in our previous studies with the [VO(ODA)L] complexes, we have found that the presence of ophen increases the reactivity of $\mathrm{VO}(\mathrm{ODA})$ toward $\mathrm{DNA}$, whereas the addition of bipy, shows a minor effect [1].

As an extension of these studies, we could now synthesize a similar complex of composition [VO(ODA)(dppz)] $3 \mathrm{H}_{2} \mathrm{O}-$ containing dppz (dppz $=$ dipyrido[3,2-a:2',3'-c]phenazine), another well-known and characterized DNA-intercalator [9-16]. The heterocyclic $\pi$-system of this molecule combines the 
chelating functions of $\alpha$-diimines or "polypyridines", such as the mentioned bipy and ophen ligands, with the electron transfer/proton transfer capacity of the 1,4-diazines [17]. As it was not possible to obtain single crystals of this new complex, adequate for crystallographic studies, its structural and geometric characteristics were derived from a theoretical DFT study. Besides, the characterization of the complex was complemented with the analysis of its FTIR and electronic absorption spectra. Finally, its antitumor activity was assayed on the MG-63 human osteosarcoma cell line in culture.

\section{Materials and Methods}

Materials

The monohydrate of $o$-phenanthroline and oxodiacetic acid was purchased from Aldrich, oxidovanadium(IV) acetylacetonate from Fluka, whereas $\mathrm{VOSO}_{4} \cdot 5 \mathrm{H}_{2} \mathrm{O}$ and all the other reagents and solvents were from Merck. The dppz ligand was obtained in the following way: $o$-phenanthroline was first transformed into 5-nitro- $O$-phenanthroline by reaction with concentrated $\mathrm{HNO}_{3}$ in the presence of oleum [18]. The nitro compound was subsequently reduced with $\mathrm{SnCl}_{2}$ to 5 -amino$o$-phenanthroline [19], which is then reacted with a $\mathrm{H}_{2} \mathrm{SO}_{4} /$ $\mathrm{HNO}_{3}$ mixture to generate 5,6-quinone-o-phenanthroline [20]. Finally, ethanolic solutions of this quinone and $o$ phenylendiamine are mixed and shortly boiled, generating the dppz which after recrystallization from aqueous ethanol generates brown-orange needles of the hemihydrate, $\mathrm{C}_{18} \mathrm{H}_{10} \mathrm{~N}_{4} \cdot 0.5 \mathrm{H}_{2} \mathrm{O}$, (m.p. $250{ }^{\circ} \mathrm{C}$ ) [20]. The precursor complex, $\left[\mathrm{VO}(\mathrm{ODA})\left(\mathrm{H}_{2} \mathrm{O}\right)_{2}\right]$, was prepared by reaction of oxidovanadium(IV) acetylacetonate and oxodiacetic acid as reported earlier $[2,6]$.

Tissue culture materials were purchased from Corning (Princeton, NJ, USA), Dulbecco's Modified Eagles Medium (DMEM), TrypLE ${ }^{\mathrm{TM}}$ from Gibco (Gaithersburg, MD, USA), and fetal bovine serum (FBS) from Internegocios SA (Argentina). All other chemicals, used in the biological assays, were from Sigma Chemical Co. (ST. Louis, MO). MG-63 cell line was purchased from ATCC (CRL1427 $\left.{ }^{\mathrm{TM}}\right)$.

Synthesis of the Complex

The new complex was obtained by slow addition of $0.145 \mathrm{~g}$ $(0.5 \mathrm{mmol})$ of dppz $\cdot 0.5 \mathrm{H}_{2} \mathrm{O}$ to $15 \mathrm{~mL}$ of a methanolic solution containing $0.117 \mathrm{~g}(0.5 \mathrm{mmol})$ of the precursor complex, at room temperature, and under continuous stirring. Although a solid compound begins to precipitate practically immediately, agitation of the mixture was continued during one more hour. The obtained precipitate was collected by filtration, washed with cold methanol, and dried in air (yield ca. $0.25 \mathrm{~g}$ ). The purity was confirmed by elemental chemical analysis (Calcd. for $\mathrm{C}_{22} \mathrm{H}_{14} \mathrm{~N}_{4} \mathrm{O}_{6} \mathrm{~V} \cdot 3 \mathrm{H}_{2} \mathrm{O}$ : C, 49.34; H, 3.73; N, 10.46; V, $9.53 \%$; found: C, 49.20; H, 3.80; N, 10.42; V, $9.47 \%$ ).

The complex is highly insoluble in all of the common solvents and, therefore, it was impossible to obtain single crystals adequate for a crystal structural analysis.

\section{Spectroscopic Characterization}

Infrared spectra in the spectral range between 4000 and $400 \mathrm{~cm}^{-1}$ were obtained with a Bruker EQUINOX 55 Fourier transform infrared spectroscopy (FTIR) instrument, using the $\mathrm{KBr}$ pellet technique. Electronic absorption spectra were measured on DMSO solutions of the complex, with a Shimadzu model UV-300 spectrophotometer, using 10-mm quartz cells.

\section{Cell Culture and Incubations}

MG-63 human osteosarcoma cells (CRL1427 TM) were grown in DMEM containing $10 \% \mathrm{FBS}, 100 \mathrm{U} / \mathrm{mL}$ penicillin, and $100 \mu \mathrm{g} / \mathrm{mL}$ streptomycin at $37{ }^{\circ} \mathrm{C}$ in $5 \% \mathrm{CO}_{2}$ atmosphere. Cells were seeded in a $75-\mathrm{cm}^{2}$ flask, and when $70-80 \%$ of confluence was reached, cells were subcultured using $1 \mathrm{~mL}$ of TrypLE $^{\mathrm{TM}}$ per $25 \mathrm{~cm}^{2}$ flask. For experiments, cells were grown in multiwell plates. When cells reached the desired confluence, the monolayers were washed with DMEM and were incubated under different conditions according to the experiments.

\section{MTT Assay}

The MTT assay was performed according to T. Mosmann [21]. Briefly, cells were seeded in a 96-multiwell dish, allowed to attach for $24 \mathrm{~h}$, and treated with different concentrations of complexes at $37^{\circ} \mathrm{C}$ for $24 \mathrm{~h}$. After that, the medium was changed, and the cells were incubated with $0.5 \mathrm{mg} / \mathrm{mL}$ MTT under normal culture conditions for $3 \mathrm{~h}$. Cell viability was marked by the conversion of the tetrazolium salt MTT (3-(4,5dimethylthiazol-2-yl)-2,5-diphenyl-tetrazolium-bromide) to a colored formazan by mitochondrial dehydrogenases. Color development was measured spectrophotometrically in a Microplate Reader (7530, Cambridge Technology, Inc, USA) at $570 \mathrm{~nm}$ after cell lysis in DMSO $(100 \mu \mathrm{L} /$ well $)$. Cell viability was plotted as the percentage of the control value.

\section{Statistical Methods}

At least three independent experiments were performed for each experimental condition. Results are expressed as percent basal and represent the mean \pm SEM. Statistical differences were analyzed using the ANOVA test. 


\section{Computational Details}

The optimized geometry of [VO(ODA)dppz] complex was obtained using the M0L6 Truhlar's functionals [22] from the density functional theory as implemented in the Gaussian 09 package [23]. The basis set of triple zeta valence quality augmented with polarization functions was used for hydrogen, carbon, and vanadium atoms [24]. For oxygen and nitrogen atoms, the same basis plus diffuse functions [25] were used.

Vibrational analysis was carried out at the same level of theory to confirm that this structure is a minimum on the potential energy surfaces. Furthermore, the bands of the infrared spectrum were also calculated to compare them with the experimental data and to support the assignment of the observed vibrational modes.

The electronic transitions were calculated at the optimized ground-state geometry within the context of the TD-DFT theory using the functional M06L and the LanL2DZ basis set, which uses Dunning D95V basis set [26] on hydrogen, carbon, nitrogen, and oxygen atoms, and Los Alamos ECP plus DZ on vanadium atom [27]. UV-visible spectral calculations were carried out including solvent effects (DMSO) through the polarizable continuum model [28] as implemented in the Gaussian 09 package to produce a number of 20 singlet-to-singlet transitions.

\section{Results and Discussion}

\section{Structural Characteristics of the Complex}

The computer-optimized structure of the complex is shown in Fig. 1. The vanadium presents a distorted octahedral coordination and the oxodiacetate anion acts as a tridentate [OOO] chelating ligand. The equatorial plane is occupied by the carboxylato oxygen atoms $\left(\mathrm{O} 2\right.$ and $\left.\mathrm{O}_{2}^{\prime}\right)$ of this ligand and the heterocyclic $\mathrm{N}$-atoms ( $\mathrm{N} 1$ and $\mathrm{N} 2$ ), whereas the axial positions are conformed by the ethereal $\mathrm{O}$-atom of oxodiacetate $(\mathrm{O} 1)$ and the vanadyl $\mathrm{V}=\mathrm{O}$-oxygen $(\mathrm{O} 5)$.

Selected bond distances and angles are shown in Table 1. The $\mathrm{V}=\mathrm{O}$ distance is similar to those determined experimentally, by X-ray crystallography, in the cases of [VO(ODA)(ophen) $] \cdot 1.5 \mathrm{H}_{2} \mathrm{O}$ [7] and [VO(ODA)(bipy)] $\mathrm{H}_{2} \mathrm{O}$ [8], the V-O distance trans to this bond, is somewhat larger in the present case, whereas the other $\mathrm{V}-\mathrm{O}$ and $\mathrm{V}-\mathrm{N}$ bonds are comparable in all these cases.

\section{IR-spectrum of [VO(ODA)(dppz) $] \cdot 3 \mathrm{H}_{2} \mathrm{O}$}

The FTIR spectrum of the complex in the most interesting spectral range, between 2000 and $400 \mathrm{~cm}^{-1}$, is shown in Fig. 2. The spectrum was not only analyzed on the basis of the results of the theoretical calculations but also by comparison with the spectra of the free oxodiacetic acid [2] and dppz [29], as well as by information provided by well known standard reference texts $[30,31]$. The proposed assignments are presented in Table 2 and are briefly commented as follows:

- The stretching vibrations of the water molecules (not shown in Fig. 2) generate a very strong and broad IR band centered at $3421 \mathrm{~cm}^{-1}$, with two weak additional bands at its lower energy side, related to $\mathrm{CH}$ and $\mathrm{CH}_{2}$ motions. The position of the strong $\mathrm{OH}$ band points to the participation of the water molecules in hydrogen bonds of medium strength $[32,33]$. The corresponding deformational mode, $\delta\left(\mathrm{H}_{2} \mathrm{O}\right)$, is surely overlapped by the strong $1657 \mathrm{~cm}^{-1}$ band.

- The carboxylate groups of ODA show the typical spectroscopic behavior expected from a monodentate interaction of this ligand with the metallic center, i.e., the antisymmetric stretching vibration presents a lower energy than those found for the $v(\mathrm{C}=\mathrm{O})$ vibration in the "free" acid $\left(1734 \mathrm{~cm}^{-1}\right)$ [2], whereas the symmetric mode lies somewhat higher than the corresponding $v(\mathrm{C}-\mathrm{O})$ mode $1309 \mathrm{~cm}^{-1}$ in the free acid) [2]. Besides, both
Fig. 1 Optimized geometry of the $[\mathrm{VO}(\mathrm{ODA})(\mathrm{dppz})]$ complex obtained by the DFT calculations

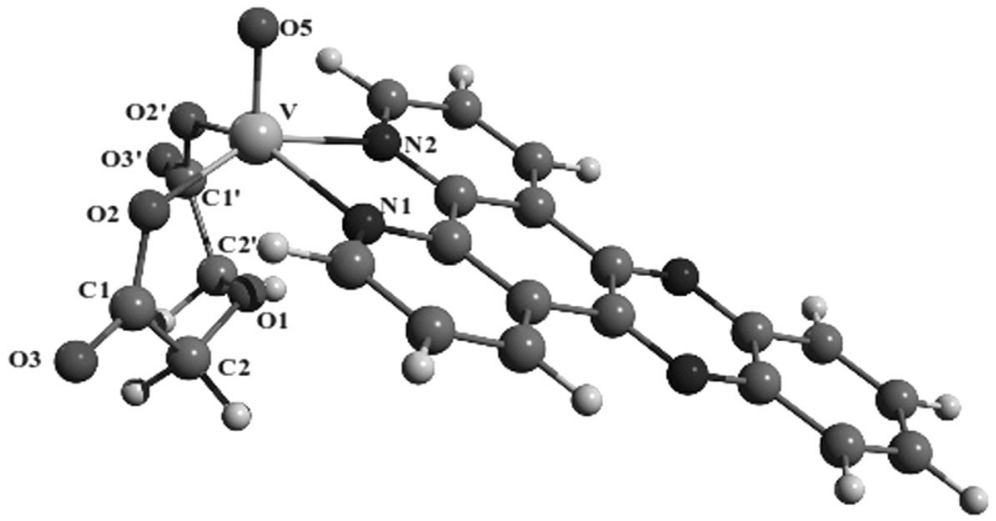


Table 1 Selected bond distances $(\AA)$ and angles $\left(^{\circ}\right)$ calculated for the [VO(ODA)(dppz)] complex

\begin{tabular}{|c|c|c|c|}
\hline V-O5 & 1.584 & $\mathrm{C} 2-\mathrm{O} 1-\mathrm{C} 2^{\prime}$ & 116.8 \\
\hline $\mathrm{V}-\mathrm{O} 2=\mathrm{V}-\mathrm{O} 2^{\prime}$ & 1.944 & $\mathrm{O} 1-\mathrm{C} 2-\mathrm{C} 1$ & 113.0 \\
\hline V-O1 & 2.408 & $\mathrm{O} 1-\mathrm{C} 2^{\prime}-\mathrm{C} 1^{\prime}$ & 113.0 \\
\hline \multirow[t]{2}{*}{$\mathrm{V}-\mathrm{N} 1=\mathrm{V}-\mathrm{N} 2$} & 2.146 & $\mathrm{~N} 1-\mathrm{V}-\mathrm{N} 2$ & 75.8 \\
\hline & & O5-V-N1 & 103.7 \\
\hline O5-V-O1 & 178.4 & O5-V-N2 & 103.7 \\
\hline $\mathrm{O} 5-\mathrm{V}-\mathrm{O} 2$ & 104.8 & $\mathrm{O} 2-\mathrm{V}-\mathrm{N} 1$ & 85.9 \\
\hline $\mathrm{O} 5-\mathrm{V}-\mathrm{O} 2^{\prime}$ & 104.8 & $\mathrm{O} 2-\mathrm{V}-\mathrm{N} 2$ & 149.0 \\
\hline $\mathrm{O} 1-\mathrm{V}-\mathrm{O} 2$ & 74.1 & $\mathrm{O} 2^{\prime}-\mathrm{V}-\mathrm{N} 1$ & 149.0 \\
\hline $\mathrm{O} 1-\mathrm{V}-\mathrm{O} 2^{\prime}$ & 74.1 & $\mathrm{O} 2^{\prime}-\mathrm{V}-\mathrm{N} 2$ & 85.9 \\
\hline $\mathrm{O} 2-\mathrm{V}-\mathrm{O} 2^{\prime}$ & 98.1 & O1-V-N1 & 77.5 \\
\hline
\end{tabular}

carboxylate stretchings also show an energy difference (about $300 \mathrm{~cm}^{-1}$ ), which is a characteristic for monodentate binding [34].

- The $v_{\mathrm{as}}(\mathrm{C}-\mathrm{O}-\mathrm{C})$ and $v_{\mathrm{s}}(\mathrm{C}-\mathrm{O}-\mathrm{C})$ motions of the ethereal moiety of ODA are slightly displaced to lower energies after interaction of its $\mathrm{O}$-atom with the metal center. The corresponding deformational mode of this grouping could not be identified with certainty because, as shown by the theoretical calculations, it is strongly coupled with other motions.

- The characteristic $v(\mathrm{~V}=\mathrm{O})$ breathing appears in the usually expected region [35] and practically at the same energy as found for [VO(ODA)(ophen) $] \cdot 1.5 \mathrm{H}_{2} \mathrm{O}[3]$ and $\left[\mathrm{VO}(\mathrm{ODA})(\right.$ bipy) $] \cdot \mathrm{H}_{2} \mathrm{O}[4]$ in agreement with the almost identical $\mathrm{V}=\mathrm{O}$ bond lengths in the three compounds. We have also tentatively assigned one of the expected $\mathrm{V}-\mathrm{O}$ metal-to-ligand vibrations at $430 \mathrm{~cm}^{-1}$.

- IR bands of the dppz rings have not been assigned in detail, because the assignments in such a large molecule, involving simultaneous motions of many atoms, are

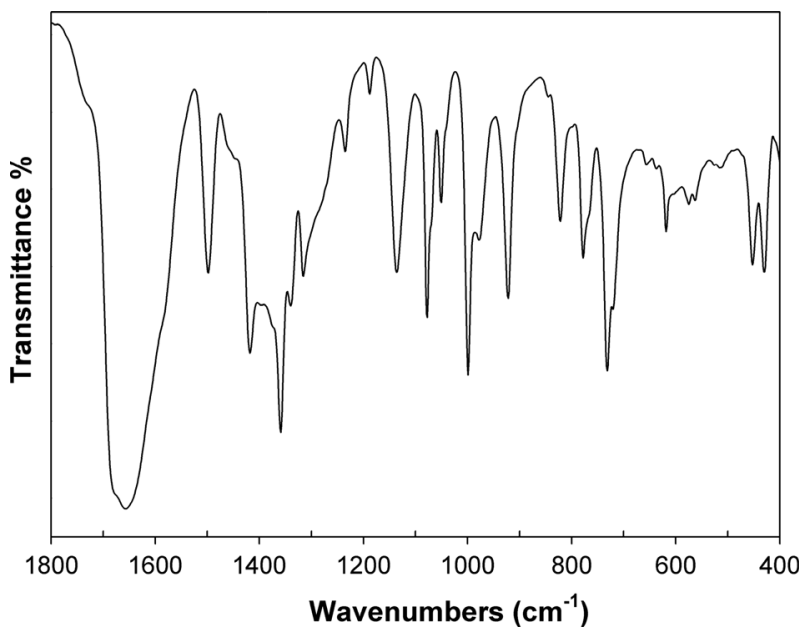

Fig. 2 FT-infrared spectra of $[\mathrm{VO}(\mathrm{ODA})(\mathrm{dppz})] \cdot 3 \mathrm{H}_{2} \mathrm{O}$ in the spectral range between 2000 and $400 \mathrm{~cm}^{-1}$
Table 2 Assignment of the FTIR spectrum of $[\operatorname{VO}(\mathrm{ODA})(\mathrm{dppz})] \cdot 3 \mathrm{H}_{2} \mathrm{O}$ (band positions in $\mathrm{cm}^{-1}$ )

\begin{tabular}{|c|c|}
\hline Band position & Assignment \\
\hline $3241 \mathrm{vs,}$ br & $v(\mathrm{OH})$ \\
\hline 3086 w, 2932 w & $v(\mathrm{CH})+v\left(\mathrm{CH}_{2}\right)$ \\
\hline $1681 \mathrm{sh}$ & $\gamma_{\text {ring }}+\delta(\mathrm{CH})$ \\
\hline 1657 vs & $v_{\mathrm{as}}\left(\mathrm{COO}^{-}\right)$ \\
\hline $1580 \mathrm{sh}$ & $\nu_{\text {ring }}$ \\
\hline $1498 \mathrm{~m}$ & $\delta\left(\mathrm{CH}_{2}\right)$ \\
\hline $1463 \mathrm{sh}, 1449 \mathrm{sh}$ & $\delta\left(\mathrm{CH}_{2}\right)+\delta(\mathrm{CH})+\nu_{\text {ring }}$ \\
\hline $1418 \mathrm{~m}$ & $\delta\left(\mathrm{CH}_{2}\right)+v_{\text {ring }}$ \\
\hline $1359 \mathrm{~s}, 1340 \mathrm{w}$ & $v_{\mathrm{s}}\left(\mathrm{COO}^{-}\right)+\delta(\mathrm{CH})$ \\
\hline $1316 \mathrm{~m}$ & $\delta(\mathrm{CH})$ \\
\hline $1289 \mathrm{sh}$ & $v(\mathrm{CN})+\tau\left(\mathrm{CH}_{2}\right)$ \\
\hline $1235 \mathrm{w}, 1188 \mathrm{w}$ & $\gamma_{\text {ring }}$ \\
\hline $1136 \mathrm{~s}$ & $v_{\text {as }}(\mathrm{C}-\mathrm{O}-\mathrm{C})+\gamma_{\text {ring }}$ \\
\hline $1078 \mathrm{~s}, 1071 \mathrm{sh}$ & $\delta_{\text {ring }}+\delta(\mathrm{CH})$ \\
\hline $1051 \mathrm{~m}, 1040 \mathrm{sh}$ & $\delta_{\text {ring }}+\delta(\mathrm{CH})$ \\
\hline $999 \mathrm{~s}$ & $v(\mathrm{~V}=\mathrm{O})$ \\
\hline $977 \mathrm{~m}, 922 \mathrm{~s}$ & $v_{\text {ring }}$ \\
\hline $822 \mathrm{~m}$ & $\nu_{\mathrm{s}}(\mathrm{C}-\mathrm{O}-\mathrm{C})+\gamma_{\text {ring }}$ \\
\hline $778 \mathrm{~m}, 769 \mathrm{sh}$ & $\delta(\mathrm{CH})+\delta_{\text {ring }}$ \\
\hline $732 \mathrm{~s}, 721 \mathrm{sh}$ & $\gamma(\mathrm{CH})+\gamma_{\text {ring }}+\rho\left(\mathrm{CH}_{2}\right)$ \\
\hline $656 \mathrm{vw}, 636 \mathrm{vw}$ & $\delta_{\text {ring }}+\delta(\mathrm{CH})$ \\
\hline $618 \mathrm{w}$ & $\gamma_{\text {ring }}+\gamma(\mathrm{CH})+\tau\left(\mathrm{CH}_{2}\right)$ \\
\hline $574 \mathrm{w}, 563 \mathrm{w}, 516 \mathrm{vw}$ & $\gamma(\mathrm{CH})+\tau\left(\mathrm{CH}_{2}\right)$ \\
\hline $452 \mathrm{~m}$ & $\delta(\mathrm{C}-\mathrm{O}-\mathrm{C})(?)$ \\
\hline $430 \mathrm{~m}$ & $\nu(\mathrm{V}-\mathrm{O})+\gamma_{\text {ring }}$ \\
\hline
\end{tabular}

$v s$ very strong, $s$ strong, $m$ medium, $w$ weak, $v w$ very weak, $b r$ broad, $s h$ shoulder

relatively complex [29]. Based on the previous studies, one can add to the data presented in Table 2 that ring modes observed at 1580, 1078/1071, and $1051 / 1040 \mathrm{~cm}^{-1}$ correspond to phenanthroline-based modes, whereas that located at $1418 \mathrm{~cm}^{-1}$ is a phenazine-based vibration [29].

- Certain vibrations are additionally complicated by superposition between ring modes and motions of part of the complex moiety. As an example, the $922-\mathrm{cm}^{-1}$ ring mode involves also a O-V-O stretching, coupled with other ODA modes. Also, the last two observed vibrations (452 and $430 \mathrm{~cm}^{-1}$ ) are partially affected by a complex deformation of the whole ODA ligand.

\section{Electronic Absorption Spectrum}

It was very difficult to obtain the electronic absorption spectrum of the complex due to its mentioned great insolubility in 
Fig. 3 Calculated electronic spectrum of the [VO(ODA)(dppz)] complex

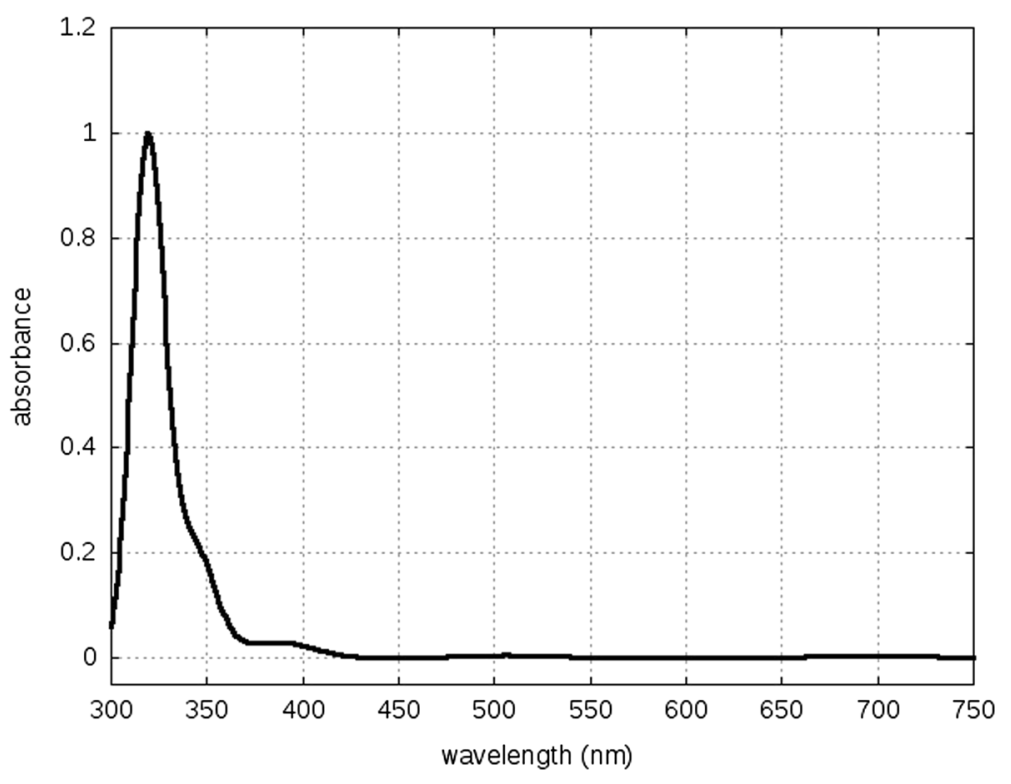

all of the common solvents. We have only obtained reproducible results with diluted DMSO solutions. In this case, we found only one absorption band located at $452 \mathrm{~nm}(\varepsilon=110 \mathrm{~L} / \mathrm{mol} \mathrm{cm})$.

The calculated electronic spectrum is shown in Fig. 3, and the electronic transitions are described in Table 3, including band positions, oscillator strengths, and proposed assignments (A and $\mathrm{B}$ indicate the electronic space of alpha and beta electrons, respectively).

The HOMO (A) is mainly constituted by the $\mathrm{d}_{\mathrm{xy}}$ orbital of the vanadium atom. $\mathrm{H}$ (B) and $\mathrm{H}-1$ (A) are constituted of a $\pi$ bonding system localized over the dppz ring, $\mathrm{H}-2$ (A) contains $p$ orbitals of the $\mathrm{O}$-atoms of ODA and $\mathrm{C}-\mathrm{C}$ and $\mathrm{C}-\mathrm{H} \sigma$ orbitals of the same ligand. The H-3 (A) and H-2 (B) involve nitrogen $p$ and $\sigma \mathrm{C}-\mathrm{N}$ orbitals from the $\mathrm{N}$-atoms lying away from the metal center.

Table 3 Calculated electronic transitions for [VO(ODA)(dppz)]

\begin{tabular}{|c|c|c|}
\hline $\begin{array}{l}\text { Wavelength } \\
(\mathrm{nm})\end{array}$ & $\begin{array}{l}\text { Oscillator } \\
\text { strength }\end{array}$ & Assignment \\
\hline 709.29 & 0.0002 & $\operatorname{HOMO}(\mathrm{A}) \rightarrow \mathrm{L}+3(\mathrm{~A})(76 \%)$ \\
\hline 682.73 & 0.0002 & $\begin{array}{l}\operatorname{HOMO}(\mathrm{A}) \rightarrow \mathrm{L}+1(\mathrm{~A})(20 \%) \\
\quad \operatorname{HOMO}(\mathrm{A}) \rightarrow \mathrm{L}+4(\mathrm{~A})(68 \%)\end{array}$ \\
\hline 505.62 & 0.0008 & $\begin{array}{l}\operatorname{HOMO}(\mathrm{A}) \rightarrow \mathrm{L}+6(\mathrm{~A})(13 \%) \\
\quad \operatorname{HOMO}(\mathrm{A}) \rightarrow \mathrm{L}+7(\mathrm{~A})(71 \%)\end{array}$ \\
\hline 396.48 & 0.0032 & $\begin{array}{c}\operatorname{HOMO}(\mathrm{A}) \rightarrow \operatorname{LUMO}(\mathrm{A})(15 \%) \\
\operatorname{HOMO}(\mathrm{A}) \rightarrow \mathrm{L}+1(\mathrm{~A})(47 \%) \\
\operatorname{HOMO}(\mathrm{A}) \rightarrow \mathrm{L}+8(\mathrm{~A})(14 \%)\end{array}$ \\
\hline 377.26 & 0.0032 & $\begin{array}{l}\text { H-3 (A) } \rightarrow \text { LUMO (A) }(47 \%), \text { H-2 } \\
\quad(B) \rightarrow \text { LUMO (B) }(47 \%)\end{array}$ \\
\hline 362.48 & 0.0005 & $\operatorname{HOMO}(\mathrm{A}) \rightarrow$ LUMO (A) $(82 \%)$ \\
\hline 343.84 & 0.0322 & $\begin{array}{l}\mathrm{H}-1(\mathrm{~A}) \rightarrow \text { LUMO }(\mathrm{A})(48 \%) \\
\text { HOMO }(\mathrm{B}) \rightarrow \text { LUMO (B) }(48 \%)\end{array}$ \\
\hline
\end{tabular}

The LUMO (A) and HOMO (B) consist both of a $\pi^{*}$ system localized on the dppz moiety, while $\mathrm{L}+1$ (A) is mainly the $d_{\mathrm{yz}}$ orbital of vanadium plus a $\pi$ system on the ring fragment closer to the metal center. $\mathrm{L}+3(\mathrm{~A})$ is the $d_{\mathrm{xz}}$ orbital of the vanadium atom, and L-4 (A) contains a certain contribution of the metal $d_{\mathrm{yz}}$ orbital. $\mathrm{L}+6(\mathrm{~A})$ and $\mathrm{L}+7(\mathrm{~A})$ are both constituted by the $d_{\mathrm{x}-\mathrm{y}}{ }^{2}{ }^{2}$ vanadium orbital, whereas $\mathrm{L}+8$ (A) is the $d_{\mathrm{z}}^{2}$ metal orbital.

As it can be seen from the results analyzed in Table 3, most of the calculated absorptions are of complex origin involving various transitions.

The measured 452-nm absorption may be eventually related to the calculated $396.48 \mathrm{~nm}$ band. Besides, bands calculated at $709.29 / 682.73 \mathrm{~nm}$ and at $505.62 \mathrm{~nm}$ eventually correspond to the 820 and $580 \mathrm{~nm}$ transitions measured in the case

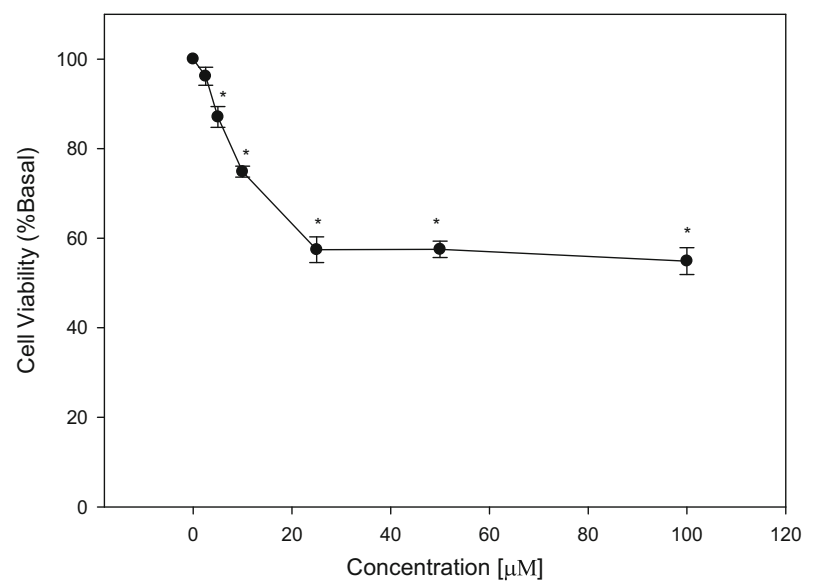

Fig. 4 Evaluation of the mitochondrial succinate dehydrogenase activity by the MTT assay in MG-63 cells in culture. Osteosarcoma cells were incubated with different doses $(25-100 \mu \mathrm{M})$ of the complex for $24 \mathrm{~h}$ at $37^{\circ} \mathrm{C}$. After incubation, cell viability was determined by the MTT assay. Results are expressed as \% basal and represent the mean \pm SEM, $n=18$. Asterisk shows significant differences vs. control $(p<0.01)$ 
of [ $\mathrm{VO}(\mathrm{ODA})(\mathrm{ophen})] \cdot 1.5 \mathrm{H}_{2} \mathrm{O}$ [7], which are characteristics for these type of complexes, but which were not found in the present case due to the commented scarce solubility of the complex.

\section{Effects of $[\mathrm{VO}(\mathrm{ODA})(\mathrm{dppz})] \cdot 3 \mathrm{H}_{2} \mathrm{O}$ on Human Osteosarcoma Cell Viability}

Multiple biological effects of vanadium have been involved in its inhibitory actions on many tumor cells [36]. Considering the high accumulation of vanadium in bone [37-39], it is of high interest to determine the effect of the new vanadium complex at the hard tissue level. Therefore, and as part of our mentioned project devoted to the characterization of vanadium complexes with antitumor properties, we have tested the effect of this new complex on human osteosarcoma cells in culture. Its action on the cellular viability was determined on MG-63 human osteosarcoma cell line, which is considered as a good model for bone tissue cancer [40].

Figure 4 shows the effects of the complex $[\mathrm{VO}(\mathrm{ODA})(\mathrm{dppz})] \cdot 3 \mathrm{H}_{2} \mathrm{O}$ on the mitochondria metabolism of MG-63 osteosarcoma cells. As it can be seen, the complex caused a concentration-related inhibition from 5 to $25 \mu \mathrm{M}$ with statistically significant differences versus basal condition $(p<0.01)$. Moreover, the compound diminished the cell viability ca. $45 \%$ in the range from 25 to $100 \mu \mathrm{M}(p<0.01)$. Nevertheless, it did not exhibit a dose response effect in this range of concentrations. Comparing the effects of the new complex with those of the previously reported complex of the oxidovanadium(IV) cation with oxodiacetate and $o$ phenantroline, [VO(ODA)(ophen)] $1.5 \mathrm{H}_{2} \mathrm{O}$ [3], it can be seen that the biological behavior of both vanadium(IV) complexes on MG-63 cells is similar [1].

On the contrary, in the evaluation of the related $\mathrm{VO}^{2+}$ complex with bipyridine [VO(ODA)(bipy)] $\mathrm{H}_{2} \mathrm{O}[4]$ and with $\left[\mathrm{VO}(\mathrm{ODA})\left(\mathrm{H}_{2} \mathrm{O}\right)_{2}\right]$ [2], considered as the precursor of this series of related compounds, the damage was observed only in the higher concentration range $(50-100 \mu \mathrm{M})$ [1]. These results reinforce again the hypothesis of the importance of using strong intercalating ligands (ophen and dppz) in the generation of new compounds with potential antitumor properties.

\footnotetext{
Acknowledgments This research was supported by the Universidad Nacional de La Plata, the Agencia Nacional de Promoción Científica y Tecnológica-ANPCyT (PICT 2218), and the Consejo Nacional de Investigaciones Científicas y TécnicasCONICET (PIP 1125 and PIP 5078). The authors are indebted to Dr. J. Zinczuk, Instituto de Química de Rosario (IQUIR/ CONICET,UNR), Rosario, Argentina, for the synthesis of dppz. IEL is a fellow from CONICET and BSPC, and SBE are members of the Research Career from CONICET. CAF acknowledges the Universidad Nacional de Catamarca for computing time.
}

\section{References}

1. León IE, Butenko N, Di Virgilio AL, Muglia CI, Baran EJ, Cavaco I, Etcheverry SB (2014) Vanadium and cancer treatment: antitumoral mechanisms of three oxidovanadium(IV) complexes on a human osteosarcoma line. J Inorg Biochem 134:106-117

2. Rivadeneira J, Barrio DA, Etcheverry SB, Baran EJ (2007) Spectroscopic characterization of a $\mathrm{VO}^{2+}$ complex of oxodiacetic acid and its bioactivity on osteoblast-like cells in culture. Biol Trace Elem Res 118:159-166

3. Leon IE, Etcheverry SB, Parajón-Costa BS, Baran EJ (2012) Spectroscopic characterization of an oxovanadium(IV) complex of oxodiacetic acid and o-phenanthroline. Bioactivity on osteoblast-like cells in culture. Biol Trace Elem Res 147:403-407

4. Leon IE, Etcheverry SB, Parajón-Costa BS, Baran EJ (2013) Spectroscopic characterization of an oxovanadium(IV) complex of oxodiacetic acid and 2,2'-bipyridine. Bioactivity on osteoblast-like cells in culture. J Mex Chem Soc 57:175-179

5. Grirrane A, Pastor A, Ienco A, Mealli C, Galindo A (2002) Synthesis and molecular structure of oxydiacetate complexes of nickel(II) and cobalt(II). Theoretical analysis of the planar and non-planar conformation of oxydiacetate ligand and oxydiacetic acid. Dalton Transact 2002:3771-3777

6. del Rio D, Galindo A, Tejedo J, Bedoya FJ, Ienco A, Mealli C (2000) Synthesis, molecular structure and properties of oxovanadium(IV) complexes containing the oxydiacetate ligand. Inorg Chem Comm 3: 32-34

7. Álvarez L, Grirrane A, Moyano R, Álvarez E, Pastor A, Galindo A (2010) Comparison of the coordination capabilities of thiodiacetate and oxydiacetate ligands through the X-ray characterization and DFT studies of $[\mathrm{VO}(\mathrm{dta})(\mathrm{phen})] \cdot 4 \mathrm{H}_{2} \mathrm{O}$ and $[\mathrm{VO}($ oda $)($ phen $)] \cdot 1.5 \mathrm{H}_{2} \mathrm{O}$. Polyhedron 29:3028-3035

8. del Rio D, Galindo A, Vicente R, Mealli C, Ienco A, Mais D (2003) Synthesis, molecular structure and properties of oxo-vanadium(IV) complexes containing the oxydiacetate ligand. Dalton Transact 2003: $1813-1820$

9. Erkkila KE, Odom DT, Barton JK (1999) Recognition and reaction of metallointercalators with DNA. Chem Rev 99:2777-2795

10. Liu HK, Sadler PJ (2011) Metal complexes as DNA intercalators. Acc Chem Res 44:349-359

11. Chen W, Turro C, Friedman LA, Barton JK, Turro NJ (1997) Resonance Raman investigation of $\mathrm{Ru}(\mathrm{phen})_{2}(\mathrm{dppz})^{2+}$ and related complexes in water and in the presence of DNA. J Phys Chem B 101: 6995-7000

12. Navarro M, Hernández C, Colmenares I, Hernández P, Fernández M, Sierraalta A, Marchán E (2007) Synthesis and characterization of $\left[\mathrm{Au}(\mathrm{dppz})_{2}\right] \mathrm{Cl}_{3}$. DNA interaction studies and biological activity against Leishmania (L) mexicana. J Inorg Biochem 101:111-116

13. Benítez J, Guggeri L, Tomaz I, Arrambide G, Navarro M, Costa Pessoa J, Garat B, Gambino D (2009) Design of vanadium mixedligand complexes as potential anti-protozoa agents. J Inorg Biochem 103:609-616

14. Benítez J, Guggeri L, Tomaz I, Costa Pessoa J, Moreno V, Lorenzo J, Avilés FX, Garat B, Gambino D (2009) A novel vanadyl complex with a polypyridyl DNA intercalator as ligand: a potential anti-protozoa and anti-tumor agent. J Inorg Biochem 103:1386-1394

15. Sánchez-Delgado RA, Anzellotti A, Suárez L (2004) Metal complexes as chemotherapeutic agents against tropical diseases: malaria, trypanosomiasis and leishmaniasis. In: Sigel A, Sigel H (eds) Metal ions in biological systems, vol. 41: Metal ions and their complexes in medication. Marcel Dekker, New York, pp 379-419

16. Navarro M, Gabbiani C, Messori L, Gambino D (2010) Metal-based drugs for malaria, trypanosomiasis and leishmaniasis: recent achievements and perspectives. Drug Disc Today 15:1070-1078 
17. Klein A, Scheiring T, Kaim W (1999) Molecular and crystal structure of an organoplatinum(II) complex with dipyrido[3,2-:2',3'-c]phenazine (dppz). Z Anorg Allg Chem 625:1177-1180

18. Smith GF, Cagle FW (1947) The improved synthesis of 5-nitro-1,10phenanthroline. J Org Chem 12:781-784

19. Koft E, Case FH (1962) Substituted 1,10-phenanthrolines. XII. Benzo and pyrido derivatives. J Org Chem 27:865-868

20. Dickeson JE, Summers LA (1970) Derivatives of 1,10phenanthroline-5-6-quinone. Aust J Chem 23:1023-1027

21. Mosmann T (1983) Rapid colorimetric assay for cellular growth and survival: application to proliferation and cytotoxicity assays. J Immunol Methods 65:55-63

22. Zhao Y, Truhlar DG (2008) The M06 suite of density functionals for main group thermochemistry, thermochemical kinetics, noncovalent interactions, excited states, and transition elements: two new functionals and systematic testing of four M06-class functionals and 12 other functionals. Theor Chem Acc 120:215-241

23. Frisch MJ, Trucks GW, Schlegel HB, Scuseria GE, Robb MA, Cheeseman JR, Scalmani G, Barone V, Mennucci B, Petersson GA, Nakatsuji H, Caricato M, Li X, Hratchian HP, Izmaylov AF, Bloino J, Zheng G, Sonnenberg JL, Hada M, Ehara M, Toyota K, Fukuda R, Hasegawa J, Ishida M, Nakajima T, Honda Y, Kitao O, Nakai H, Vreven T, Montgomery JJA, Peralta JE, Ogliaro F, Bearpark M, Heyd JJ, Brothers E, Kudin KN, Staroverov VN, Keith T, Kobayashi R, Normand J, Raghavachari K, Rendell A, Burant JC, Iyengar SS, Tomasi J, Cossi M, Rega N, Millam JM, Klene M, Knox JE, Cross JB, Bakken V, Adamo C, Jaramillo J, Gomperts R, Stratmann RE, Yazyev O, Austin AJ, Cammi R, Pomelli C, Ochterski JW, Martin RL, Morokuma K, Zakrzewski VG, Voth GA, Salvador P, Dannenberg JJ, Dapprich S, Daniels AD, Farkas O, Foresman JB, Ortiz JV, Cioslowski J, Fox DJ (2010) Gaussian-09. Gaussian Inc., Wallingford

24. Weigend F, Ahlrichs R (2005) Balanced basis sets of split valence, triple zeta valence and quadruple zeta valence qualify for $\mathrm{H}$ to $\mathrm{Rn}$ : design and assessment of accuracy. Phys Chem Chem Phys 7:32973305

25. Rappoport D, Furche F (2010) Property-optimized Gaussian basis sets for molecular response calculation. J Chem Phys 133:134105
26. Dunning TH Jr, Hay PJ (1976) In: Schaefer HF III (ed) Modern theoretical chemistry, vol 3. Plenum, New York, pp 1-28

27. Hay PJ, Wadt WR (1985) Ab initio effective core potentials for molecular calculations. Potentials for the transition metal atoms Sc to $\mathrm{Hg}$. J Chem Phys 82:270

28. Barone V, Cossi M (1998) Quantum calculation of molecular energies and energy gradients in solution by a conductor solvent model. J Phys Chem A 102:1995-2001

29. Matthewson BJ, Flood A, Polson MIJ, Armstrong C, Phillips DL, Gordon KC (2002) Vibrational spectra of dipyrido[3,2-a:2',3'c]phenazine and its radical anion analyzed by ab initio calculations and deuteration studies. Bull Chem Soc Jpn 75:933-942

30. Lin-Vien D, Colthup NB, Fateley WG, Grasselli JG (1991) The handbook of infrared and Raman characteristic frequencies of organic molecules. Academic, Boston

31. Smith B (1999) Infrared spectral interpretation. CRC, Boca Raton

32. Siebert H (1966) Anwendungen der Schwingungsspektroskopie in der Anorganischen Chemie. Springer, Berlin

33. Libowitzky E (1999) Correlation of O-H stretching frequencies and $\mathrm{O}-\mathrm{H}{ }^{\cdots} \mathrm{O}$ hydrogen bond lengths in minerals. Monatsh Chem 130: 1047-1059

34. Nakamoto K (1997) Infrared and Raman spectra of inorganic and coordination compounds, 5th edn. Wiley, New York

35. Baran EJ (2001) Review: spectroscopic studies of oxovanadium coordination compounds. J Coord Chem 54:215-238

36. Bishayee A, Wagharay A, Patel MA, Chatterjee M (2010) Vanadium in the detection, prevention and treatment of cancer: the in vivo evidence. Cancer Lett 294:1-12

37. Rehder D (2008) Bioinorganic vanadium chemistry. Wiley, Chichester

38. Baran EJ (2008) Vanadium detoxification: chemical and biochemical aspects. Chem Biodivers 5:1475-1484

39. Rehder D (2012) The potentiality of vanadium in medicinal applications. Future Med Chem 4:1823-1837

40. Mohsen AB, Machado I, Cai Y, Schaefer KL, Serra M, Hogendoorn PC, Llombart-Bosch A, Cleton-Jansen AM (2011) Functional characterization of osteosarcoma cell lines provides representative models to study the human disease. Lab Investig 91:1195-1205 